\author{
Review Article \\ www.ijrap.net (ISSN:2229-3566)
}

\title{
A REVIEW ON AYURVEDIC VIEW OF PATHOPHYSIOLOGY OF DIABETES MELLITUS
}

\author{
Aditya Bhat ${ }^{1 *}$, Geetha Kumari S. ${ }^{2}$ \\ ${ }^{1}$ Associate Professor, Department of Swasthavritta and Yoga, Shree RMD Ayurveda College and Hospital Wagaldhara, \\ Gujarat, India \\ ${ }^{2}$ Associate Professor, Department of Kaumarabhritya, Shree RMD Ayurveda College and Hospital, Wagaldhara, \\ Gujarat, India
}

Received on: 14/10/19Accepted on: 26/11/19

\begin{abstract}
*Corresponding author
E-mail: adityabhat24@gmail.com
\end{abstract}

DOI: $10.7897 / 2277-4343.11014$

\begin{abstract}
Diabetes mellitus has been explained in Ayurvedic texts many centuries ago as the disease Madhumeha. It is understood as a metabolic disease resulting due to excessive energy intake and lack of energy expenditure. The disease has been explained to involve multiple causative factors like faulty diet and lifestyle as well as hereditary factors. The pathogenesis of the disease is mentioned to involve multiple tissues with a predominance of Meda (adipose tissue), Mamsa (skeletal tissue) and Kleda (body fluids). The disease is understood in Ayurveda as causing progressive depletion of tissues of the body. Over a period of time this leads to aggravation of Vatadosha which eliminates Ojus (a vital substance of body) through urinary passages.
\end{abstract}

Keywords: Madhumeha, diabetes melliitus, kapha, meda

\section{INTRODUCTION}

Ayurveda considers Madhumeha as a variety of Vataja Prameha which closely resembles the disease Diabetes Mellitus. Diabetes mellitus is characterized by multisystem involvement, complex metabolic abnormalities and varied clinical presentations. It causes significant mortality and morbidity through cardiovascular, renal, eye diseases and limb amputations. Diabetes mellitus is an important cause of end stage renal disease and non-traumatic amputations, attributed to $30 \%$ of preventable blindness and a significant cause of cardiovascular mortality ${ }^{1}$. WHO data suggests there are 31.7 million people suffering from DM in India.

In the conventional medicine the disease is not curable but can be managed with medications, diet and lifestyle modifications. However, the overall outcome is not encouraging and as patients are not satisfied with their quality of life, they often seek the help of complementary and alternative systems of medicine. As the disease has a complex and heterogeneous aetio-pathogenesis the management strategies should be holistic in nature to target these. Ayurveda which has a legacy of more than 5000 years offers a holistic approach to many lifestyle diseases including diabetes. It can play a pivotal role in tackling the menace of diabetes.

In Ayurveda, diabetes is known as a variety of Prameha, a group of diseases of urine. Prameha's which are 20 in number are considered to be the result of excessive anabolism. Madhumeha is that stage of the disease wherein the tissues of the body are depleted as a result of chronicity of the disease and aggravation of Vata takes place. Madhumeha involves all the three Doshas with a predominance of Vata and multiple Dooshyas, with a predominance of Meda (adipose tissue), Mamsa (skeletal muscle) and Kleda (body fluids). The cardinal feature of Madhumeha is excessive quantity and abnormal quality of urine wherein it resembles honey in characteristics. Generally, Madhumeha is considered to be incurable. However, to evolve definite and reliable management strategies for diabetes its aetio-pathogenesis should be analyzed in the background of Ayurvedic and modern concepts.

\section{Review of literature}

Aetiology

The aetiology of Madhumeha can be studied under the following headings:

- Aharasambandhi (related to diet)

- Viharasambandhi (related to lifestyle)

- Beejadosha (hereditary factors)

- Manasika Nidana (psychological factors)

\section{Aharasambandhi Nidana}

Excessive consumption of anabolic food causes Prameha ${ }^{2}$. Consumption of food rich in sweet, sour and salty taste well as those with qualities liker heavy, unctous, cold, liquid and slimy cause diabetes. Some food articles when consumed regularly are implicated in the causation of diabetes. These are curd, meat of aquatic animals, milk, jaggery, new grains, fatty food, alcoholic beverages and sugarcane.

\section{Viharasambandhi Nidana}

Some of the lifestyle related things are implicated in the causation of diabetes. These include using comfortable bed, excessive sleep, less physical activity, thoughtlessness, not undergoing body cleansing, not taking bath, not walking sufficiently, daytime sleep, laziness and sitting for long hours. 


\section{Beejadosha}

Acharya Charaka has considered Prameha as a disease resulting from Beejadosha ${ }^{3}$. The term Beeja in this context refers to Shukra (Sperm) and Shonita (Ovum) of parents which were affected by the Doshas during the time of conception ${ }^{4}$. That means When Beeja is vitiated by the Dosha which caused Prameha in that parent, the offspring resulting from that Beeja also gets Prameha. Acharya Sushruta has included Prameha as one among Sahajavyadhis and has described that it results from Beejadosha in either of the parents ${ }^{5}$. According to Charaka, affliction of Beeja or Beejabhaga by Doshas at the time of conception leads to diseases of the organ or system which are derived from that Beeja or Beejabhaga ${ }^{6}$. Chakrapani, a commentator of Charaka Samhita, opines that a person born to Prameha patient is likely to get affected by it $^{7}$.

\section{Manasika Nidana}

The mental factors mentioned as causes of Madhumeha are: Udvega (anxiety)

Shoka (grief)

\section{Pathogenesis}

Acharya Charaka explains that all Pramehas result due to increase of Kapha, Meda and Kleda ${ }^{8}$. According to Acharya Vagbhata, Kapha is the Dosha which initiates all varieties of Prameha ${ }^{9}$. Exposure to causative factors leads to aggravation of Kapha which circulates in the whole body due to pre-existing changes in body. Kapha combines with excess and abnormal Meda (fat) and vitiates it. Later, Kapha and Meda combine with Kleda (body fluid) and Mamsa (skeletal muscle). Vititiation of Kleda and lodgment of Kapha-Meda complex in Basti (urinary system) leads to excessive and abnormal urine formation.

\section{DISCUSSION}

The causative factors implicated by Ayurveda in the causation of Prameha point towards intake of excess quantity of food and that of high calorie, intake of simple sugars, food stuffs having a high glycemic index and saturated fat. Among the lifestyle factors reduced physical activity, having daytime sleep, leading a sedentary life are quoted as predisposing factors for Prameha. The role of hereditary and genetic factors in the causation of diabetes is also very much emphasized as Beejadosha. Finally, various forms stress which is told as anxiety and grief are also implicated as cause for diabetes.

Following three factors play important roles in the pathogenesis of Prameha:

1. Bahudrava Shleshma (Excessively fluid nature of Kapha)

2. Bahu abaddha medas (Excess and watery fat)

3. Bastidusti (Vitiation of Basti)

\section{Bahudrava Shleshma}

Kapha is considered as the initiating Dosha in Prameha. There will be both qualitative and quantitative vitiation of Kapha. Dravaguna (fluid nature) of Kapha is said to be increased ${ }^{10}$. Normal Kapha is said to possess Ghana (soild) and Sthira (firm) qualities. When it becomes excessively fluidic it is considered abnormal and it circulates all over the body. Chakrapani opines that only Bahudrava Shleshma can cause Prameha and not Alpadravashleshma (Kapha which is less fluidic) ${ }^{11}$. This increase in fluidity leads to increase in the volume of body fluids and this fluid gets converted into urine in the urinary system.

\section{Bahu Abaddha Medas}

Medas is the foremost Dooshya (tissue affected) involved in Prameha. The two abnormalities in it are Bahutwa and Abaddhatwa $^{12}$. Bahutwa refers to excessive quantity. Chakrapani interprets Abaddha as Asamhata which mean broken down ${ }^{13}$. Modern pathology explains that elevated levels of free fatty acids are important in the pathogenesis of type 2 diabetes. This is due to increased lipolysis. Intra-abdominal central adipose tissue releases a number of hormones, steroids such as cortisol and a variety of peptides called adipokines which act on specific receptors to influence sensitivity to insulin in other tissues.

\section{Bastidusti}

Most of the Ayurvedic texts have mentioned Basti as the site where the lodgment of Doshas takes place in Prameha. Bahudravashleshma along with Bahu abaddha medas and other Dooshyas circulate all over the body, reaches and get lodged in Basti (Urinary apparatus). Thus, Basti is not the primary organ involved in Prameha but a remote system on which the effects of pathogenesis are reflected. Charaka describes that, Doshas on reaching Basti produce vitiation of urine and lead to Prameha ${ }^{14}$. Also, Basti is the site where excess Kleda gets converted to urine. It is well known that when blood glucose concentration exceeds the renal threshold for glucose, glucose appears in urine. Excessive concentration of glucose causes osmotic diuresis.

Two types of pathogenesis are mentioned for Madhumeha ${ }^{15}$ :

\section{Avarana \\ 2. Dhatukshaya}

\section{Avarana}

Excessive Kapha, Pitta, Meda and Mamsa produce Avarana (obstruction) to the movements of Vata. This leads to vitiation of Vata. Vata takes Ojas (a vital substance) out of the body through urinary passages and this leads to Madhumeha ${ }^{16}$. This is similar to the modern concept of insulin resistance which results due to numerous qualitative and qualitative abnormalities of insulin signaling pathway including down-regulation of insulin receptors. Obesity and excess circulating free fatty acids are the causes of insulin resistance.

\section{Dhatukshaya}

When Vata is aggravated it causes elimination of Dhatus (tissues) through the urinary passage and results in Dhatukshaya (depleted state of tissues) ${ }^{17}$. As per modern pathology, in type 2 diabetes beta cells of the pancreas produce excess insulin to maintain glucose concentration in normal state. Over a period of time the secretary function of beta cells gets reduced. This is partly due to a phenomenon called gluco toxicity. That is, persistent hyperglycemia depletes the secretary granules of beta cells.

\section{CONCLUSION}

Diabetes is considered to be a group of heterogeneous diseases. Ayurveda considers this disease as a group of conditions caused due to improper diet and lifestyle which lead to a state of positive energy balance in the body. The disease involves multiple Doshas which regulate different functions in the body and multiple Dooshyas which are rendered abnormal due to influence of the Doshas. Excessive and abnormal body fat is an early abnormality in the disease. Later, other tissues are also affected, and the disease becomes multi-systemic. The disease process gets reflected in the urinary system of the body where the symptoms and the complications of the disease are common. The disease 
progresses over a period of time to that stage in which the body tissues are gradually depleted and a negative energy balance state is reached. Different management strategies should be designed at different stages of the disease as to address the underlying pathology. Also, the management strategies should vary according to person's Prakruti, strength, stage of the disease, age and metabolic capability.

\section{REFERENCES}

1. Siddharth N. Shah Diabetology, API Textbook of Medicine, Volume $2,8^{\text {th }}$ edition, The Association of Physicians of India, Mumbai; 2008. p. 1042-1082.

2. Agnivesha, Santarpaneeya adhyaya, Charaka samhita with Ayurveda Deepika commentary of Chakrapanidatta, edited by Vaidya Yadavji Trikamji Acharya, $8^{\text {th }}$ edition, Chaukhambha Sanskrit Sansthan, Varanasi; 2004. p. 295.

3. Agnivesha, Prameha Chikitsa, Charaka Samhita with Ayurveda Deepika commentary of Chakrapanidatta edited by Vaidya Yadavji Trikamji Acharya, Chaukhambha Sanskrit Sansthan, Varanasi, Reprint; 2009. p. 199.

4. Sushruta, Prameha Chikitsa, Sushruta Samhita with Nibandhasangraha commentary of Sri Dalhanacharya and Nyayachandrika Panjika of Sri Gayadasacharya, edited by Vaidya Yadavji Trikamji Acharya and Kavyateertha Narayan Ram Acharya, $6^{\text {th }}$ edition, Chaukhambha Orientalia, Varanasi; 1997. p. 451.

5. Agnivesha, Mahatigarbhaavakranti adhyaya, Charaka Samhita with Ayurveda Deepika commentary of Chakrapanidatta edited by Vaidya Yadavji Trikamji Acharya, 8th edition Chaukhambha Sanskrit Sansthan, Varanasi; 2004. p. 771.

6. Agnivesha, Prameha Chikitsa, Charaka Samhita with Ayurveda Deepika commentary of Chakrapanidatta edited by Vaidya Yadavji Trikamji Acharya, published by Chaukhambha Sanskrit Sansthan, Varanasi, Reprint; 2009. p. 199.

7. Agnivesha, Prameha Chikitsa, Charaka Samhita with Ayurveda Deepika commentary of Chakrapanidatta edited by Vaidya Yadavji Trikamji Acharya, Chaukhambha Sanskrit Sansthan, Varanasi, Reprint; 2009. p. 197.

8. Vagbhata, Prameha Nidana, Astanga Sangraha, Text with English translation, notes and index by Prof. K.R.
Srikanthamurthy, $5^{\text {th }}$ edition, Chaukhambha Orientalia, Varanasi; 2005. p. 204.

9. Agnivesha, Prameha Nidana, Charaka Samhita with Ayurveda Deepika commentary of Chakrapanidatta edited by Vaidya Yadavji Trikamji Acharya, $8^{\text {th }}$ edition, Chaukhambha Sanskrit Sansthan, Varanasi, p. 501-502.

10. Agnivesha, Prameha Nidana, Charaka Samhita with Ayurveda Deepika commentary of Chakrapanidatta edited by Vaidya Yadavji Trikamji Acharya, $8^{\text {th }}$ edition, Chaukhambha Sanskrit Sansthan, Varanasi; p. 501-502.

11. Agnivesha, Prameha Nidana, Charaka Samhita with Ayurveda Deepika commentary of Chakrapanidatta edited by Vaidya Yadavji Trikamji Acharya, $8^{\text {th }}$ edition, Chaukhambha Sanskrit Sansthan, Varanasi; p. 503.

12. Agnivesha, Prameha Nidana, Charaka Samhita with Ayurveda Deepika commentary of Chakrapanidatta edited by Vaidya Yadavji Trikamji Acharya, $8^{\text {th }}$ edition, Chaukhambha Sanskrit Sansthan, Varanasi; p. 503.

13. Agnivesha, Prameha Chikitsa, Charaka Samhita with Ayurveda Deepika commentary of Chakrapanidatta edited by Vaidya Yadavji Trikamji Acharya, Chaukhambha Sanskrit Sansthan, Varanasi, Reprint; 2009. p. 188.

14. Vagbhata, Prameha Nidana, Nidanasthana, Astanga Hridaya with Sarvangasundara commentary of Arunadatta and Ayurvedarasayana commentary of Hemadri, edited by Pandit Hari Sadasiva Sastri Navre, Chaukhambha Surabharati Prakashan, Varanasi, reprint; 2002. p. 502-506.

15. Agnivesha, Kiyantahshirasiya adhyaya, Charaka Samhita with Ayurveda Deepika commentary of Chakrapanidatta edited by Vaidya Yadavji Trikamji Acharya, $8^{\text {th }}$ edition, Chaukhambha Sanskrit Sansthan, Varanasi; 2004. p. 242.

16. Agnivesha, Prameha Chikitsa, Charaka Samhita with Ayurveda Deepika commentary of Chakrapanidatta edited by Vaidya Yadavji Trikamji Acharya, Chaukhambha Sanskrit Sansthan, Varanasi, Reprint; 2009. p. 188.

\section{Cite this article as:}

Aditya Bhat and Geetha Kumari S. A review on Ayurvedic view of Pathophysiology of Diabetes mellitus. Int. J. Res. Ayurveda Pharm. 2020; 11(1):17-19 http://dx.doi.org/10.7897/2277$\underline{4343.11014}$

Disclaimer: IJRAP is solely owned by Moksha Publishing House - A non-profit publishing house, dedicated to publishing quality research, while every effort has been taken to verify the accuracy of the content published in our Journal. IJRAP cannot accept any responsibility or liability for the site content and articles published. The views expressed in articles by our contributing authors are not necessarily those of IJRAP editor or editorial board members. 